

\title{
Parenteral nutrition with fish oil supplements is safe and seems to be effective in severe preterm neonates with respiratory distress syndrome
}

Laurent Beghin, Laurent Storme, Stephanie Coopman, Thameur Rakza, Frederic Gottrand

\section{To cite this version:}

Laurent Beghin, Laurent Storme, Stephanie Coopman, Thameur Rakza, Frederic Gottrand. Parenteral nutrition with fish oil supplements is safe and seems to be effective in severe preterm neonates with respiratory distress syndrome. Acta Paediatrica, 2015, 104 (11), pp.E534-E536. 10.1111/apa.13091 . hal-02177087

\section{HAL Id: hal-02177087 \\ https://hal.univ-lille.fr/hal-02177087}

Submitted on 8 Jul 2019

HAL is a multi-disciplinary open access archive for the deposit and dissemination of scientific research documents, whether they are published or not. The documents may come from teaching and research institutions in France or abroad, or from public or private research centers.
L'archive ouverte pluridisciplinaire HAL, est destinée au dépôt et à la diffusion de documents scientifiques de niveau recherche, publiés ou non, émanant des établissements d'enseignement et de recherche français ou étrangers, des laboratoires publics ou privés. 
Parenteral nutrition with fish oil supplementation in premature neonates with severe respiratory distress syndrome. A preliminary study

Laurent Béghin ${ }^{1,2}$, Laurent Storme ${ }^{3}$, Stéphanie Coopman ${ }^{2}$, Thameur Rakza ${ }^{3}$, Frédéric Gottrand ${ }^{1,2}$.

1 U995 Inserm, Université Lille 2, 59037 Lille, France.

2 CIC-PT-1403-Inserm-CH\&U, CHRU de Lille, 59037 Lille, France.

3 EA 4489, Environnement Périnatal et Croissance, Université Lille2, 59037 Lille, France

In the early stage of life, premature neonates are fed with a parenteral nutrition solution (1). For years, lipid emulsion based on soybean oil have been used in neonatal intensive care unit (NICU). Soybean oil is rich in n-6 polyunsaturated fatty acids (PUFAs) and has a relatively low antioxidant and anti-inflammatory content. Prematurity is often associated with severe respiratory distress syndrome, which is caused by a lack of surfactant together with the combined effects of mechanical ventilation and oxygen therapy. In this context of ventilation-induced lung injury and oxygen toxicity, premature neonates with severe respiratory distress syndrome have a high risk of developing bronchopulmonary dysplasia (BPD). BPD is defined in 3 grades: mild when supplemental oxygen is needed for 28 days but room air at 36 weeks corrected gestational age or at discharge, moderate when supplemental oxygen is required for 28 days and $\mathrm{FiO} 2<0.30$ at 36 weeks corrected gestational age or at discharge, and severe when supplemental oxygen is needed for 28 days and $\mathrm{FiO} 2>0.30$ or positive pressure support at 36 
weeks corrected gestational age or at discharge (2). Some studies have stated that BPD is considered as an inflammatory disease $(3 ; 4)$. Animal study (5) and clinical observation (6) have shown that n-3 long-chain PUFAs (LCPUFAs ; e.g., eicosapentaenoic acid (EPA: 20:5n-3) and docosahexaenoic acid (DHA: 22:6n-3)) decrease pulmonary inflammation. In this context, some neonatologists (7-9) have used parenteral nutrition solution supplemented by pharmaceutical fish oil to improve the lung fatty acid profile and improve immune function in preterm neonates (10).

Pharmaceutical fish oil supplementation can be achieved using the commercially available SMOFlipid $®$ emulsion which is approved for preterm infant nutrition (Fresenius Kabi, Sèvres, France). Studies have shown that SMOFlipid® emulsion was safe and well tolerated in more than 150 preterm neonates, including those in three clinical trials (7-9). However, any benefits of SMOFlipid® emulsion noted in clinical trial are not specific to the beneficial effects of n-3 LCPUFAs because SMOFlipid® contains n-3 LCPUFAs as well as medium-chain triglycerides and n-6 LCPUFAs, which have different physiological effects (11). Omegaven ${ }^{\circledR}$ is a pure n-3 LCPUFA lipid emulsion. Here, we present a preliminary study of using Omegaven ${ }^{\circledR}$ as a new fish LCPUFAs rich lipid emulsion for use in the treatment of preterm neonate with respiratory distress syndrome.

For this study and according to Declaration of Helsinki, written informed consent was obtained from both parents of the preterm neonate, and the study was approved by the Ethical Committee of Lille (Comité de Protection des Personnes Nord-Ouest IV dans la Recherche Biomédicale de Lille $\mathrm{N}^{\circ}$ 04/70) and the French competent authority (AFSSAPS). This study included 12 preterm neonates 
(median gestational age of 30 weeks [27-32]) with severe respiratory distress syndrome, which was defined as a fraction of inspired oxygen of 0.35 (oxygen saturation measured by pulse oxymetry between $90 \%$ and $95 \%$ ) at $36 \mathrm{~h}$ of age together with the need for mechanical ventilation (median duration: 5 days [326]) according to the classification of Couchard et al (12). All premature neonates with severe respiratory distress received artificial surfactant (proactant alpha) within the first hours of life.

Before randomization, all preterm neonates were continuously fed with parenteral nutrition solution and a minimal continuous enteral feeding using pooled breast milk from our local lactarium. According to the European Society for Parenteral and Enteral Nutrition and the European Society for Pediatric Gastroenterology, Hepatology and Nutrition consensus, the target of parenteral nutrition solution was $2 \mathrm{~g} / \mathrm{kg} / \mathrm{d}$ for lipids (started at birth at $0.5 \mathrm{~g} / \mathrm{kg} / \mathrm{d}$ and gradually increased to reach $2 \mathrm{~g} / \mathrm{kg} / \mathrm{d}$ ), $18 \mathrm{~g} / \mathrm{kg} / \mathrm{d}$ for glucose (started at birth at 8 $\mathrm{g} / \mathrm{kg} / \mathrm{d}$ and gradually increased by steps of $2 \mathrm{~g} / \mathrm{kg}$ to reach $18 \mathrm{~g} / \mathrm{kg} / \mathrm{d}$ ) and $4 \mathrm{~g} / \mathrm{kg} / \mathrm{d}$ for proteins. This target was not modified with advancement of enteral feeding. Parenteral nutrition solution with fish oil supplementation (Omegaven ${ }^{\circledR} 10 \%$ ) or control oil (Intralipid® 10\%) was started at $42-54$ h of life and was continued until 12-13 days of life. Randomization was performed using sealed envelopes centralized in the NCIU. Randomization was equilibrated by block size of 6 , according to a ratio of intervention to control subjects of 2:1 (4 intervention/2 control). Double blinding of the identity of the commercial lipid emulsions: Omegaven ${ }^{\circledR} \quad 10 \%$ vs Intralipid ${ }^{\circledR} 10 \%$ was assured by specific stickers that masked the labeling information and included the subject's randomized number 
(and Good Clinical Practice quality assurance information specifically requested for Clinical Trial).

The blinded lipid emulsions tested were diluted at ratio 1/10 in a syringe (for infusion pump) in sterile condition at the NCIU unit : $50 \mathrm{ml}$ of lipid emulsion was prepared daily by mixing $5 \mathrm{ml}$ of blinded Omegaven ${ }^{\circledR} 10 \%$ or $5 \mathrm{ml}$ of blinded Intralipids ${ }^{\circledR} 10 \%$ with $45 \mathrm{ml}$ of Intralipid ${ }^{\circledR} 20 \%$. This procedure achieved a final lipid composition of $18 \%$ in each groups.

Both at baseline and at 28 days of age, the preterm neonate' weight did not differ between groups (Table 1). Clinical outcomes at the baseline and at 28 days of age are shown in Table 1. Some sepsis (by Gram-negative bacteria species) occurred early (1/8 in interventional group and $3 / 4$ in control group) and only one in each group were until present at 28 days of life (Table 1). The blood clinical parameters are presented in Table 2. These parameters did not differ between the two groups at the baseline and at the end point of 28 days except for platelet count, which was lower at 28 days of life in the control group than in the n-3 LCPUFA group. No adverse drug reactions, adverse events of special interest, or serious adverse events were observed during the 28-day study period. We observed a significantly shorter oxygen therapy duration in the n-3 LCPUFA group compared with the control group: 33 days [12-100] vs 254 days [42-593], respectively ( $\mathrm{p}=0.048$, Mann-Whitney $U$ test).

Minimizing lung injury in preterm neonates with severe respiratory distress syndrome is one of the main concerns in the NICU, and nutritional intervention is a promising method to achieve this (13). This study reports for the first time the use of Omegaven ${ }^{\circledR}$ as a new source of n-3 LCPUFAs for parenteral nutrition solution with fish oil supplementation in preterm neonates with severe respiratory 
distress syndrome. The strong anti-inflammatory effect of EPA and DHA, which has been demonstrated in both animal models (5) and human conditions such as asthma, chronic obstructive pulmonary disease, and cystic fibrosis, may decrease the risk of developing BPD $(14 ; 15)$. Our study shows that Omegaven ${ }^{\circledR}$ could be used as a source of n-3 LCPUFAs for parenteral nutrition solution with fish oil supplementation in preterm neonates with severe respiratory distress syndrome. The greater oxygen therapy duration observed in the control group could be due to the presence of sepsis at baseline of a potential effect of n-3 LCPUFAs in interventional group. In this context, effects of n-3 LCPUFAs on oxygen therapy duration should be tested in a blinded randomized clinical trial.

\section{Acknowledgements:}

We thank the children and their parents who took part in this study. Data quality assurance, logistical, statistical and technical assistance were assumed by the Clinical Investigation Center of Lille, (CIC-PT-1403-Inserm-CHRU). Good Clinical Practices and regulatory aspects were performed by Lille University Hospital. Financial support was assumed by a grant from the French Ministry of Health (PHRC 2004/R1912), Fresenius Kabi®, France (2004 ; Dr C. YVON), and Guigoz laboratories (2004). Pr Frédéric Gottrand has received consulting fees from Numico Clinical Nutrition, lecture fees from SHS and grant support from Danone Research. The remaining authors state no conflict of interest.

\section{Reference List}

(1) Koletzko B, Goulet O, Hunt J, Krohn K, Shamir R. 1. Guidelines on Paediatric Parenteral Nutrition of the European Society of Paediatric Gastroenterology, Hepatology and Nutrition (ESPGHAN) and the European Society for Clinical Nutrition and Metabolism (ESPEN), Supported by the European Society of Paediatric Research (ESPR). J Pediatr Gastroenterol Nutr 2005; 41 : S1-87. 
(2) Jobe AH, Bancalari E. Bronchopulmonary dysplasia. Am Respir Crit Care Med 2001; 163:1723-29.

(3) Bott L, Beghin L, Devos P, Pierrat V, Matran R, Gottrand F. Nutritional status at 2 years in former infants with bronchopulmonary dysplasia influences nutrition and pulmonary outcomes during childhood. Pediatr Res 2006; 60 : 340-4.

(4) Stevens TP, Harrington EW, Blennow M, Soll RF. Early surfactant administration with brief ventilation vs. selective surfactant and continued mechanical ventilation for preterm infants with or at risk for respiratory distress syndrome. Cochrane Database Syst Rev 2007;(4):CD003063.

(5) Pierre M, Husson MO, Le BR, Desseyn JL, Galabert C, Beghin L, et al. Omega-3 polyunsaturated fatty acids improve host response in chronic Pseudomonas aeruginosa lung infection in mice. Am J Physiol Lung Cell Mol Physiol 2007;292 : L1422-L1431.

(6) Fasano E, Serini S, Piccioni E, Innocenti I, Calviello G. Chemoprevention of lung pathologies by dietary n-3 polyunsaturated fatty acids. Curr Med Chem 2010; $17: 3358-76$.

(7) Tomsits E, Pataki M, Tolgyesi A, Fekete G, Rischak K, Szollar L. Safety and efficacy of a lipid emulsion containing a mixture of soybean oil, medium-chain triglycerides, olive oil, and fish oil: a randomised, doubleblind clinical trial in premature infants requiring parenteral nutrition. $J$ Pediatr Gastroenterol Nutr 2010;51 : 514-21.

(8) Rayyan M, Devlieger H, Jochum F, Allegaert K. Short-term use of parenteral nutrition with a lipid emulsion containing a mixture of soybean oil, olive oil, medium-chain triglycerides, and fish oil: a randomized double-blind study in preterm infants. J Parenter Enteral Nutr 2012 ;36 : $81 \mathrm{~S}-94 \mathrm{~S}$.

(9) D'Ascenzo R, Savini S, Biagetti C, Bellagamba MP, Marchionni P, Pompilio A, et al. Higher Docosahexaenoic acid, lower Arachidonic acid and reduced lipid tolerance with high doses of a lipid emulsion containing 15\% fish oil: A randomized clinical trial. Clin Nutr 2014;33 : 1002-9.

(10) Grimm H. A balanced lipid emulsion- A new concept in parenteral nutrition 2005.

(11) Zgheel F, Alhosin M, Rashid S, Burban M, Auger C, Schini-Kerth VB. Redox-sensitive induction of Src/PI3-kinase/Akt and MAPKs pathways activate eNOS in response to EPA:DHA 6:1. PloS One 2014; 9 : e105102.

(12) Couchard M, Polge J, Bomsel F. [Hyaline membrane disease: diagnosis, radiologic surveillance, treatment and complications]. Ann Radiol (Paris) 1974;17 : 669-83.

(13) Jobe AH. Parental nutrition with fish oil. J Pediatr 2011; 159 : A3. 
(14) Groneck P, Schmale J, Soditt V, Stutzer H, Gotze-Speer B, Speer CP. Bronchoalveolar inflammation following airway infection in preterm infants with chronic lung disease. Pediatr Pulmonol 2001;31 : 331-8.

(15) Kallapur SG, Jobe AH. Contribution of inflammation to lung injury and development. Arch Dis Child Fetal Neonatal 2006;91 : F132-F135. 
Table 1: Weight and clinical outcome at baseline and at 28 days of age

\begin{tabular}{|c|c|c|c|c|}
\hline & \multicolumn{2}{|c|}{$\begin{array}{l}\text { n-3 LCPUFAs } \\
\text { group } \\
\\
\mathbf{n}=\mathbf{8}\end{array}$} & \multicolumn{2}{|c|}{$\begin{array}{l}\text { Control } \\
\text { group } \\
\mathbf{n = 4}\end{array}$} \\
\hline & baseline & 28 days & baseline & 28 days \\
\hline Weight (Kg) & $\begin{array}{c}1.45 \\
{[0.93-1.83]}\end{array}$ & $\begin{array}{c}1.70 \\
{[1.07-2.47]}\end{array}$ & $\begin{array}{c}1.51 \\
{[0.93-1.80]}\end{array}$ & $\begin{array}{c}2.24 \\
{[1.15-2.32]}\end{array}$ \\
\hline Late onset sepsis & 0 & 1 & 0 & 1 \\
\hline Pulmonary hypertension* & 4 & 0 & 3 & 0 \\
\hline Necrotizing enterocolitis & 0 & 0 & 0 & 1 \\
\hline
\end{tabular}


Table 2: Blood biological parameters at baseline and at 28 days of age

\begin{tabular}{|c|c|c|c|c|c|c|}
\hline \multirow[t]{2}{*}{ Median (ranges) } & \multicolumn{2}{|c|}{$\begin{array}{c}\text { n-3 LCPUFAs } \\
\text { group } \\
\\
\mathbf{n}=\mathbf{8}\end{array}$} & \multicolumn{2}{|c|}{$\begin{array}{c}\text { Control } \\
\text { Group } \\
\mathbf{n}=\mathbf{4}\end{array}$} & \multirow[t]{2}{*}{$\mathrm{p}^{1}$} & \multirow[t]{2}{*}{$\mathrm{p}^{2}$} \\
\hline & baseline & 28 days & baseline & 28 days & & \\
\hline Haemoglobin $(g / L)$ & $135.0[85.1-165.7]$ & $110.2[76.0-128.2]$ & $130.2[112.5-149.3]$ & 113.8 [100.0-128.7] & 0.4 & 0.7 \\
\hline Haematrocrit (\%) & $32.4[10.0-44.5]$ & 32.9 [21.6-38.7] & $37.8[32.4-45.7]$ & $33.6[31.0-38.3]$ & 0.6 & 0.4 \\
\hline $\operatorname{RBCs}\left(10^{12}\right.$ counts $\left./ \mathrm{L}\right)$ & $3.6[2.2-4.2]$ & $3.3[2.4-4.9]$ & $3.4[2.7-4.6]$ & $4.0[3.5-4.9]$ & 0.8 & 0.9 \\
\hline WBCs $\left(10^{9}\right.$ counts $\left./ L\right)$ & $12.1[7.4-20.8]$ & $13.8[6.3-20.4]$ & $10.0[9.6-14.2]$ & $16.6[13.2-20.4]$ & 0.9 & 0.8 \\
\hline Platelets $\left(10^{9}\right.$ counts $\left./ L\right)$ & $185[67-228]$ & 299 [236-332] & $146[110-170]$ & $167[151-270]$ & 0.9 & 0.01 \\
\hline Triglycérides $(\mathrm{mmol} / \mathrm{L})$ & $0.9[0.6-1.0]$ & $0.8[0.4-1.2]$ & $0.7[0.5-0.9]$ & $0.8[0.7-0.9]$ & 0.9 & 0.8 \\
\hline Créatinine $(\mu \mathrm{mol} / \mathrm{L})$ & $32.0[17.7-78.0]$ & $47.4[39.0-55.8]$ & $76.6[45.8-85.0]$ & $42.8[38.0-49.2]$ & 0.9 & 0.4 \\
\hline Total bilirubin $(\mu \mathrm{mol} / \mathrm{L})$ & 228 [125-392] & $65[45-92]$ & 180 [117-339] & 69 [38-92] & 0.7 & 0.6 \\
\hline C-reactive protein $(m g / d L)$ & $7.7[0.1-48]$ & $0.1[0.1-23]$ & $3.1[0.1-6.0]$ & $3.6[0.1-6]$ & 0.2 & 0.4 \\
\hline
\end{tabular}

${ }^{1}$ U-Mann-Whitney test between LCPUFAs group and control group at baseline

U-Mann-Whitney test between LCPUFAs group and control group at 28 days of age

WBCs $=$ White Blood Cells 
Figure 1: Box plot of duration of continuous mechanical ventilation (a) and oxygen therapy duration (b) at 28 days of age in the 2 groups


* U-Mann Whitney 
